УДК 908(477)

\title{
ДОСЛІДЖЕННЯ ВОЛИНІ У ПІВДЕННОУКРАЇНСЬКІЙ ІСТОРІОГРАФІЇ (ХІХ - ПОЧАТОК ХХ ст.)
}

\author{
Олександр МУЗИЧКО \\ Одеський національний університет імені I. І. Мечникова \\ кафедра історії України \\ вул. Дворянська, 2, Одеса, 65082, Україна \\ e-mail: sandro06@ukr.net
}

\begin{abstract}
Мета студії - дослідити питання про зв' язки у галузі історичної науки між двома віддаленими одна від одної українських земель: Волині та Південної України. Певні елементи цієї теми наявні у дослідженнях деяких наших попередників, але комплексно тема не розглядалася. У студіях південноукраїнських істориків Волинь фігурувала в історико-краєзнавчих нарисах туристичного типу, загальному контексті досліджень соціяльно-правового устрою Великого князівства Литовського, у працях, спеціяльно присвячених історії Волині, що було відображено і в їх назвах.

Ключові слова:Волинь, Південна Україна, М. Комаров, Д. Дорошенко, М. Смірнов, В. Біднов, М. Істомін, С. Дубков.
\end{abstract}

У часи авторитарного українофобського проросійського режиму ЯнуковичаТабачника робилися великі зусилля, аби українська історична наука була втиснута в рамки так званого “регіонального підходу”. Дуже просто було “освятити” цей підхід авторитетом самого В. Б. Антоновича. Проте, відповідний підхід В. Б. Антоновича, по-перше, виник та розвивався в конкретно-історичних умовах доби, коли це був єдиний легальний спосіб “заховати” та плекати у межах русистики україністику, а, по-друге, був зорієнтований підкріпити ідею соборности України у перспективі. Він грунтувався передусім на етнічному підході, адже передбачав вивчення усього масиву етно-історично українських земель, тобто території заселеної здебільшого етнічними українцями. Натомість "регіональнийо підхід мав зовсім протилежне, антисоборницьке та антинаціональне скерування, хоча часто і більш чи менш вдало завуальоване. Цей підхід був спрямований не на пошук спільного в історії, щоб зміцнити Україну як територію титульної нації та усіх спільнот, що прихильні до ідеї побудови України, а обгрунтовував так звані “регіональні розбіжності чи специфіку”, що, мовляв, історично склалися i тому не мають бути знівельовані. Це освячувало консервацію мовного та історично-ментального російщення в окремих регіонах, дедалі тісніше втягувало більшу частину України у простір “русского мірао. Деструктивна сутність цієї “кліополітики” давно була очевидною для україноцентричних кіл і тому після Революції Гідности він поступово, якщо не повністю зник, то істотно трансформувався. Позитивно, що сьогодні з новою силою актуалізувався соборницький принцип дослідження історії України. У контексті цього принципу, 
ISSN 2078-6077. Наукові зошити історичного факультету Львівського університету. 2018-2019. Випуск 19-20. Proceedings of History Faculty of Lviv University. 2018-2019. Issue 19-20.

метою статті поставлено простудіювати питання про зв'язки в галузі історичної науки між двома віддаленими одна від одної українських земель: Волині та Південної України. Певні елементи цієї теми наявні у студіях деяких наших попередників, але комплексно тема не розглядалася ${ }^{1}$.

Незважаючи на відстань, Волинь та Південна Україна пов'язані між собою багатьма історичними нитками, людськими долями, освячені кров'ю героїв. Наприклад, один із лідерів українського руху Іван Луценко, загинув на Волині в бою з російськими комуністами в 1919 р., був похований на станції Красилів, де нещодавно йому встановили меморіяльну дошку. 3 Одесою, Акерманом, Кримом тісно була пов'язана Леся Українка, яка мала тут низку близьких друзів (одесити М. Комар та його родина), часто відвідувала південну частину України.

Переходячи до основного змісту нашої статті, зауважимо, що Південь та Північний Захід України начебто “обмінялися” істориками в особах народжених на Волині Осипа Міхневича (один з перших в Одесі істориків філософії, освіти), Аполлона Скальковського (засновника наукових студій козацтва та загалом Південної України, за що його називали “Нестор”, чи “Геродот” Новоросійського краю), Дмитра Сигаревича (популяризатор історії України в Одесі, дослідник кобзарства), які більшу частину свого життя працювали саме в Південній Україні та народженого на Півдні Василя Кравченка, який тривалий час працював у Житомирі. Вже в 1920-х роках народжена в Одесі О. Ф. Лагодовська, згодом відомий археолог, отримала вищу освіту в Житомирі. Попри те, що ці особи підтримували певний зв'язок зі своїми малими батьківщинами (зокрема, В. Кравченко друкував в Одесі свої оповідання, був знайомий з одеситом М. Комаром та катеринославцем Д. Яворницьким), вона опинилася на маргінесі їх наукових зацікавлень².

Хоча і незначною мірою, але волинський напрямок проглядає в діяльності деяких південноукраїнських товариств історичного профілю. У 1888 р. Одеське товариство історії та старожитностей просило викладача одеських гімназій А. О. Матвєєва під час його подорожі у Волинську губернію, у Крем'янецький та Дубенський повіти, оглянути пам'ятки старовини. Також він оглянув місце Берестецької битви, про що хотів доповісти на одному з археологічних з'їздів, але не встиг ${ }^{3}$.

На одному із засідань Історико-філологічного товариства при Новоросійському університеті викладач гімназії М. П. Істомін виступив 3 доповіддю про князя Єремію Вишневецького. Праця одеського громадського діяча та аматора-історика Михайла Комара про козацького ватажка Антона

\footnotetext{
${ }^{1}$ I. Ярмошик, Волинь в історико-краєзнавчих дослідженнях XIX-XX століть.(Житомир, 2006), 216.

2 “Листи вчених до Д. І. Яворницькогоо, ред. С. Абросимова та ін., Епістолярна спадщина академіка Д. І. Яворницького, No.1, (1997), 277-278.

3 Листування товариства з закладами, Державний архів Одеської області, ф. 93, оп. 2, спр. 5, арк. 129, 364.
} 
Головатого, в 1901 р. викликала відгук у волинській газеті “Волынь”. Автор, що заховався за криптонімом, розкритикував те, що ініціятор видання, “Товариство для поширення дешевих книг”, мовляв, висмикує епізоди з історії України, замість того, аби видати цілісну історію України. На цей відгук у Херсоні заперечив місцевий автор Г. А. Коваленко у газеті "Юг”.

Катеринославська вчена архівна комісія (КВАК) та Херсонський міський музей старожитностей Херсонського краю встановили обмін виданнями 3 “Товариством дослідників Волині" А.С. Синявський, А.Б. Вітстедт, О.Г. Рікман, М. В. Биков, О. Т. Мельніков розглядали описи Волинської скарбові палати, відбираючи ті справи, що варто зберігати. Проміжним підсумком було рішення, що кілька справ про євреїв колоністів треба зберегти, бо вони містять дані з історії землеволодіння на Волині

Головним волинознавчим епізодом у діяльності КВАК було оприлюднення на сторінках восьмого випуску іiі періодичного видання "Летописи" статті Д. І. Дорошенка "Козацькі могили під Берестечком”. У статті історик висвітлив історію битви та описав свої враження від стану пам'яток на підставі відвідин ним влітку 1911 р. вперше у своєму житті західної частини Волині, цього, за його характеристикою “найбагатшого в історичному плані краю, що зберіг масу пам'яток сивої старовини”. Автор не обмежився описом лише козацьких могил: цікаві його зауваги про збереження людністю Берестечка старого побуту, чудової української мови. Пізніше у своїх спогадах Д. Дорошенко навів додаткові деталі про свою подорож на Волинь ${ }^{7}$. Ініціятором подорожі був західноукраїнський мовознавець I. М. Зілинський. Компанію історикові також склав український письменник Модест Левицький. Дуже коротко в мемуарах описавши враження від місця битви, Д. Дорошенко, натомість загадав про свої відвідини Рівненщини та Острожчини, барона Ф.Р. Штейнгеля та Д. В. Марковича. Д. Дорошенко відвідав Волинський музей, що заснував барон та облаштував видатний археолог М. Ф. Біляшівський. Свою подорож на Волинь Д. Дорошенко популяризував на сторінках катеринославського українського часопису “Дніпрові Хвилі”. У цих оповіданнях та в мемуарах найпринциповіший, пам'яттєвий елемент, зазнав відчутної еволюції, порівняно з текстом статті історика 1908 року. В мемуарах, написаних уже одним з провідників Української революції, Д. Дорошенко зробив показову редукцію: текст статті 1908 р. був сповнений поваги до російського священика з Почаєва, що облаштував козацькі могили, щоправда, наповнивши

\footnotetext{
${ }^{4}$ Летопись Екатеринославской ученой архивной комиссии, № 6. (1910): 259; Летопись Херсонского городского музея древностей Херсонского края за 1914 год, (Херсон, 1916): 48.

${ }^{5}$ Летопись Екатеринославской ученой архивной комиссии, №. 6, (1910): 247-248, 253, 255.

6 Дмитрий Дорошенко, “Козацкие могилы под Берестечком,” Летопись Екатеринославской ученой архивной комиссии, №. 8, (1912): 65-81.

7 Дмитро Дорошенко, Мої спогади про недавнє минуле (1901-1914), (Вінніпег, 1949), 129135.
} 
ISSN 2078-6077. Наукові зошити історичного факультету Львівського університету. 2018-2019. Випуск 19-20. Proceedings of History Faculty of Lviv University. 2018-2019. Issue 19-20.

напис на дубовому хресті зі згадкою про загибель 30 тисяч козаків (явний перегук зі спартанцями) “за славу русскую” із суто російським ідеологічним змістом.

Натомість у статтях, надрукованих у збірці “По рідному краю” в 1919 р., цих священиків вже висміює та засуджує ${ }^{8}$. У мемуарах їх просто не згадано. У книжці “По рідному краю” Д. Дорошенко описав відвідини Крем’янця та Луцька9. Місто, яке нагадало йому кримський Бахчисарай, залишило в нього позитивні враження ${ }^{10}$. Він навів досить докладний опис історії Крем'янця, що дало підстави йому зробити висновок про це місто як про славне, але занепале, хоча як історика його тішило: місто наче законсервоване. На яскравий опис “заслужив” також Луцьк. Звичайно, Д. Дорошенко не міг не відвідати Луцький замок, де був розчарований, що обивателі залишали надписи на стінах.

У мемуарах історик описав менш відому другу подорож на Волинь у наступному, 1912-му, році ${ }^{11}$. На цей раз серед його супутників був інший видатний катеринославський історик В. О. Біднов. Для В. Біднова ця подорож стала прологом для його вже тривалих зв'язків з Волинню в 1920 -1930-х роках.

Місцем перетину волинських та південноукраїнських істориків були Археологічні з'їзди - найбільший форум науковців-гуманітаріїв у Російській імперії, що проводився кожне триріччя. Два з них відбулися на території Південної України - Одеський (1884) та Катеринославський (1905). Учасниками Одеського з'їзду були три особи: відомий волинський аматор старовини та громадській діяч Сигизмунд Люба-Радзиминський $(1843$ - 1928) з Крем'янця, згодом один 3 засновників Товариства дослідників Волині; Бронислав Мечиславович Прушинський з Житомира та Петро Васильович Симонов з Острога. Одним 3 делегатів на Катеринославському археологічному з'їзі була відомий педагог та історик-аматор Єлизавета Іванівна де Вітте з Крем'янця Волинської губернії.

Під час IX археологічного з'їзду у Вільно одеський історик А. В. Лонгінов виголосив доповіді “Про родинні зв'язки між руськими князями та угорським королівським домом" та "Про князя Любарта-Феодора Ольгерда та його нащадків князів Сангушків”, що обидві частково висвітлювали тему історії Волині ${ }^{12}$. Щодо другої доповіді, то йому опонував С. Люба-Радзиминський. У першій доповіді А. Лонгінов спирався на Волинський літопис та висвітлив родинні зв'язки князя Володимира Васильковича Волинського.

\footnotetext{
${ }^{8}$ Дмитро Дорошенко, По рідному краю: (подорож. враження й замітки), (Львів, 1930), 156.

9 Дмитро Дорошенко, По рідному краю: (подорож. враження й замітки), (Львів, 1930), 37-94.

${ }^{10}$ Там само, 73-74.

${ }^{11}$ Дмитро Дорошенко, Мої спогади про недавнє минуле (1901-1914), (Вінніпег, 1949), 136139.

12 Антон Лонгинов, “О князе Любарте Ольгердовиче и его потомках, князьях Сангушках,” Труды Виленского отделения Московского предварительного комитета Съезда, (Вильно, 1893), 275-311. Антон Лонгинов, “О родственных связях русских князей с угорским королевским домом," Труды Виленского отделения Московского предварительного комитета Съезда, (Вильно, 1893), 313-328.
} 
ISSN 2078-6077. Наукові зошити історичного факультету Львівського університету. 2018-2019. Випуск 19-20. Proceedings of History Faculty of Lviv University. 2018-2019. Issue 19-20.

На XI археологічному з’їзді у Києві вже згаданий М. П. Істомін як делегат від одеських історичних товариств виголосив дві доповіді про фрески XVIIXVIII ст. у храмах та костелах України, зокрема, Волині та про головні риси іконографії на Волині в XVI-XVIII ст. ${ }^{13}$

Вчений намагався відокремити візантійські та західноевропейські впливи у волинському іконописанні. На тому ж з'їзді одеський історик О. І. Маркевич виголосив програмову доповідь “Про збереження старовинних пам'яток”. У контексті питання, що є темою цієї статті, важливими $є$ ті місця доповіді, де О. Маркевич згадував про Волинь. На самому початку доповіді він описав своє перебування в Луцькому замку, що перегукується з описаними вище враженнями Д. Дорошенка. Там він обурився процесом оновлення стін замку, про що заявив волинському губернаторові, намагаючись зупинити варварський підхід до старовини. У Крем'янці він був свідком того, як хлопці ламали камінь у стіні фортеці на так званій горі Бони. На підставі цих та інших випадків руйнування старовини О. Маркевич пропонував об'єднати зусилля різних товариств щодо охорони історико-культурної спадщини ${ }^{14}$.

Волинь згадувалася на сторінках відомих праць південноукраїнських істориків Д. І. Яворницького, М. Ф. Комара (Комарова) та М. М. Аркаса (у полеміці щодо його праці, “Історії України-Руси”, взяв участь видатний волинянин В. Липинський). Значно виразнішими є волинознавчі аспекти у працях низки інших південноукраїнських істориків. Випускник Київського університету Святого Володимира Ф. І. Леонтович був учнем професора Київського університету М. Д. Іванишева - дослідника історії Волині ранньомодерного часу ${ }^{15}$. Працюючи у Рішельєвському ліцеї в Одесі, Ф. Леонтович написав праці про історію правового статусу євреїв та селян України, порівняння Литовських статутів та Руської Правди, що великою мірою грунтувалися на вивченні Другого, Волинського, Литовського Статуту та волинських актах XVI-XVIII ст. ${ }^{16}$

\footnotetext{
${ }^{13}$ Труды одиннадияатого археологического съезда в России в Киеве, т. 2. (Москва, 1902), 61, 97.

${ }^{14}$ Труды одиннадцатого археологического съезда в России в Киеве. т. 2. (Москва, 1902), $159-160$.

${ }^{15}$ Анатолій Силюк, “130 років від дня смерті М. Д. Іванішева (1811-1874) - українського історика, правника, археографа, дослідника Волині,” Календар знаменних і пам'ятних дат Волині на 2004 р., (Луцьк: Волинська обласна державна адміністрація, Волинський краєзнавчий музей, 2003), 97-99.

${ }^{16}$ Федор Леонтович, "Исторический обзор постановлений о евреях в России”, Сион, (1861, 10, 17, 24 ноября; 1, 8, 15, 22, 29 декабря; 1862, 13, 20, 27 апреля).; Федор Леонтович, "Историческое исследование о правах литовско-русских евреев,о Киевские университетские известия, №. 3, (март 1864): 1-43; №. 4. (апрель),: 1-48; Федор Леонтович, "Крестьяне юго-западной России по литовскому праву XV-XVI ст.,о Киевские университетские известия, No. 10. (1863):1-48; No. 11,: 1-40; Федор Леонтович, "Русская Правда и Литовский Статут, в видах настоятельной необходимости включить литовское законодательство в круг истории русского права," Киевские университетские известия, №. 2, (1865):1-25; No. 3,: 1-31; No. 4,: 1-38.
} 
ISSN 2078-6077. Наукові зошити історичного факультету Львівського університету. 2018-2019. Випуск 19-20. Proceedings of History Faculty of Lviv University. 2018-2019. Issue 19-20.

Професор катедри російської історії Новоросійського університету, вихованець В. Антоновича, I. А. Линниченко - фахівець з історії середньовічної Галичини i Волині. В Одесі він опрацьовував грамоти Галицько-волинських князів, готуючи їх до видання, розшукував додаткові матеріяли в західноевропейських архівах. Кілька праць одеського періоду прямо стосуються історії Волині. Зокрема, в 1880-х роках він написав рецензії на відомі роботи О. Андріяшева та П. Батюшкова. На відповідні студії він зорієнтував кількох своїх учнів. Срібною медаллю був нагороджений Б. В. Вахевич за працю “Юридичне та економічне становище селян у Південно-Західній Росії XVI ст.”. Інший учень професора П. Г. Клепацький, написав фундаментальний твір про історію Київської землі у складі Великого князівства Литовського, Руського та Жемайтійського, що був нагороджений золотою медаллю. У цю добу до складу Київської землі належали і Волинській землі. Отож, П. Г. Клепацький присвятив окремі розділи своєї роботи Овруцькому та Житомирському повітам, їх заселенню, соціяльноекономічному розвиткові ${ }^{17}$.

Подібно до праць одеситів, Волинь була “вмонтована" в загальне тло історії часів “литовської доби” історії України у праці катеринославця Василя Біднова. Якщо нариси його певний час близького колеги Д. Дорошенка належали до жанру популяризації історії та краєзнавства, то праця В. Біднова 1908 р. про становище православної церкви в Речі Посполитій була магістерською дисертацією, суто науковим твором, хоча і забарвленим конфесійним, православним підходом ${ }^{18}$. Автор оцінював події з точки зору православних, зокрема, шляхти, міщанства та духовенства Волині. В. Біднов ретельно зібрав актові відомості про незадоволення волинян зусиллями католиків, що були спрямовані окатоличувати Волинь.

Викладач російської історії Рішельєвського ліцею, а згодом і Новоросійського університету М. П. Смірнов (1833-1877) у 1860 р. видав у Санкт-Петербурзі працю “Доля Червоної чи Галицької Русі”, яку захистив як магістерську дисертацію. Він простежив основні етапи розвитку Галичини від Київських часів до 1387 р., до іiї анексії Польщею. М. Смірнов опрацьовував джерельну та історіографічну базу впродовж своїх наукових відряджень до Львова, Волинської та Подільської губерній у 1859 р. та у Вільно в 1867 p. ${ }^{19}$. Дослідник зосередився головно на Галичі, але побіжно торкнувся й історії Волині. Ця праця була видана зі скороченнями в 1886 р. у Тернополі в перекладі українською мовою в “Руській Історичній Бібліотеціо за редакцією О. Барвінського.

${ }^{17}$ Павел Клепатский, Очерки по истории Киевской земли. Т. І. Литовский период, (Одесса, 1912), 595.

${ }^{18}$ Василий Беднов, Православная Церковь в Польще и Литве (no Volumina Legum), (Екатеринослав, 1908).

19 “Отчет проф. М.П. Смирнова о его поездке в г. Вильно,о Приложение к cm. 14 протокола заседания Ученого Совета Новороссийского университета от 18.11.1867, 75-77. 
Тему магістерської дисертації М. Смірнов продовжив та розширив у великій статті 1863 року “Боротьба між Литвою та Польшею про права на Волинь та Поділля" 20. Докторська дисертація М. Смірнова "Ягелло-Яків-Владислав та перше з’єднання Литви та Польщі” 1868 року видання теж торкалася теми боротьби за Волинь ${ }^{21}$.

На тлі цих праць, де Волинь фігурувала у більш загальному контексті, головним волинознавчим твором південноукраїнської історіографії слід вважати студію приват-доцента Новоросійського університету П. А. Іванова "Історична доля Волинської землі”, яку він захистив у своїй альма-матер Київському університеті Св. Володимира ${ }^{22}$. Вона була однією з 11 монографій про історію окремих українських регіонів, що вийшли протягом 1881-1903 років в рамках обласного “проєкту В. Антоновича". Цій праці передувала низка публікацій П. Іванова на ту ж саму тему ${ }^{23}$. Хоч праця грунтувалася ще на студентському доробку історика київських часів його навчання, він працював над нею головно вже перебуваючи тривалий час на півдні України, а саме у Миколаєві від 1887 р., а від 1893 р. в Одесі.

Завдання глибоких студій історії середньовічної Волині ускладнювалося тим, що незадовго до того вже з'явилася праця на аналогічну тему іншого вихованця В. Антоновича - О. Андріяшева. Більшість оригінального тексту роботи зайняла полеміка з думками попередніх дослідників Волині, особливо стосовно генеалогії та хронології князів. Так, у питанні про постать Юрія II Болеслава П. Іванов пристав до О. Андріяшева та М. Любавського. Вони вважали, що джерела говорять про двох різних князів. Зворотну думку відстоювали Ф. Режабек, М. Дашкевич, А. Лонгінов, І. Філевич, М. Грушевський, А. Прохазка, О. Бальцер, І. Линниченко. Докладніше П. Іванов висвітлив соціяльноекономічну та культурну історію (так звану “внутрішню”) Волині, на що вказує, наприклад, I. Крип'якевич у своїй монографії про Галицько-Волинське князівство ${ }^{24}$.

Оцінки праці одесита були полярними. В. Антонович вважав, що “Загалом праця Іванова відрізняється великою сумлінністю у вивченні джерел та літератури предмету, повнотою їх вивчення і цілком науковими прийомами історичної

\footnotetext{
${ }^{20}$ Михаил Смирнов, “Спор между Литвою и Польшею о правах на Волынь и Подолию,” Торжественный акт Ришельевского лицея по случаю окончания 1862-1863, 5-71.

${ }^{21}$ Михаил Смирнов, Ягайло-Яков-Владислав и первое соединение Литвы с Польшей, ч. 1. (Одесса, 1868), 259.

22 П. Иванов, Исторические судьбы Волынской земли, (Одесса, 1895), 317.

${ }^{23}$ П. Иванов, “Несколько слов по поводу сочинения А.В. Лонгинова “Князь Федор-Любарт Ольгердовичо, Чтения в историческом обществе Нестора летописиа в Киеве, т. 8. Библиография; П. Іванов, "Картка $з$ історії Волині на початку XIV ст.," Записки наукового товариства імені Шевченка, т. 2, (Львів, НТШ, 1893), 119-146.

${ }^{24}$ Іван Крип'якевич, Галииько-Волинське князівство, відп. ред. Ярослав Ісаєвич (Львів, Інститут українознавства ім. І.Крип’якевича НАН України, 1999), 19-20.
} 
ISSN 2078-6077. Наукові зошити історичного факультету Львівського університету. 2018-2019. Випуск 19-20. Proceedings of History Faculty of Lviv University. 2018-2019. Issue 19-20.

критики"25. Цей схвальний відгук став основою ухвали надати П. Іванову магістерський ступінь. Завжди суворий у своїх оцінках М. Грушевський, твердив: “деякі уваги не уймають ваги і ціни праці Іванова, що є корисним внеском в українсько-руську історіографію, і ми щиро зичимо дальшого успіху і розвою діяльности нового робітника на дорогій нам ниві" ${ }^{26}$. Історик відзначив оригінальність підходу автора, що для опису вірувань волинян використав етнографічний матеріял з Волині XIX ст. Такий спосіб було вперше застосовано у вивченні історії поодиноких давніх земель. М. Грушевський зауважив, що П. Іванов ширше розглянув історію Волині першої половини XIV ст. і відзначив значний інтерес цього розділу праці. Він солідаризувався з одеським колегою щодо зображення князя і віча основою політичного устрою землі.

М. Довнар-Запольський та I. Линниченко зосередились на негативних сторонах праці, відзначивши фактичні помилки автора, його невміння критично підходити до джерел та думок інших авторів ${ }^{27}$. Попри критику, праці П. Іванова були прийняті до уваги в подальшій історіографії Волині та середньовічної України ${ }^{28}$.

Серед неакадемічних вчених (хоча це аж ніяк не відображає їх високого рівня знань та вмінь) минулим подіям на Волині присвятив увагу головний єврейський історик, що працював певний час в Україні, а саме в Одесі у 1890-1903 роках, С. М. Дубнов. У двох статтях на основі актів, виявлених у польських архівах, він висвітлив кагальну організацію євреїв Волинського воєводства та лад євреїв Острога в XVI - XVIII ст. ${ }^{29}$. Статті С. Дубнова цінні не лише для історіографії євреїв, але й для студій з історії Волині загалом, зокрема, для вивчення діяльности династії князів Острозьких. Вочевидь, не усі оцінки та факти, які навів автор, може сприйняти українська історіографія. Так, згідно з єврейською традицією, переоціненою вже істориками-євреями 1920-1930-х років (С. Я. Боровой), С. Дубнов сприймав козаків як “банди”, що різали євреїв Волині. 3 іншого боку, в дусі холоднокровного позитивіста, С. Дубнов робив висновок про відсталість та забитість єврейської общини Острога у XVIII ст.

Одеський священик та православний історик I. X. Стрельбицкий у своїй праці висвітлив історію церковних соборів на Волині, що призвели до заснування Греко-

\footnotetext{
${ }^{25}$ Володимир Антонович, “Рец. на: Иванов П. А. “Исторические судьбы...,” Киевские университетские известия, №. 3, (1896): 3-5.

${ }^{26}$ Михайло Грушевський, “Рец. на: Иванов П.А. “Исторические судьбы...,” Записки Наукового Товариства ім. Шевченка, т. 9 бібліографія, (1896): 4-9.

${ }^{27}$ Митрофан Довнар-Запольський, “Рец. на: Иванов П.А. “Исторические судьбы...,” Журнал министерства народного просвещения, №. 4, (1896): 332-377; Иван Линниченко, Отзыв об ученых трудах П. Иванова. (Одесса, 1905), 15.

${ }^{28}$ Михайло Кучинко, Волинська земля X-середини XIV cm. (Луцьк, 2002), 17, 279.

${ }^{29}$ Семен Дубнов, “Еврейская старина в г. Остроге (1532-1792),о Восход, Октябрь, (1894):322 ; Семен Дубнов, “Областные кагальные сеймы в воеводстве Волынском и в Белоруссии (16661764),о Восход, Апрель, (1894): 25-45.
} 
Католицької церкви ${ }^{30}$. Перебуваючи у межах традиційно-негативного православного підходу до Унії, цей автор, тим не менше, підійшов грунтовно до своєї теми, опрацювавши значну джерельну базу.

Отже, у дослідженнях південноукраїнських істориків Волинь фігурувала в історико-краєзнавчих нарисах туристичного типу (Д. Дорошенко), загальному контексті досліджень соціяльно-правового устрою Великого князівства Литовського (Ф. Леонтович, П. Клепацький), у працях, що спеціяльно висвітлювали події на Волині (М. Смірнов, П. Іванов, М. Істомін, С. Дубнов, I. Стрельбицький). Попри те, що лише праці останньої групи можна зарахувати до фундаментального внеску в історіографію Волині, усі згадані групи, праці та автори виконували важливу місію: у віддаленому від Волині Півдні знайомили передусім місцевих читачів з цією самобутньою українською землею.

\title{
RESEARCH OF THE HISTORY OF VOLYNIA IN HISTORIOGRAPHY OF THE SOUTHERN UKRAINE IN THE XIX - EARLY XX CENTURIES
}

\author{
Oleksandr MUZYCHKO \\ Odesa National University named after I. I. Mechnikov \\ Department of History of Ukraine \\ Dvoryanska str., 2, Odesa, 65082, Ukraine \\ e-mail: sandro06@ukr.net
}

The purpose of this article is to study the relationship of historical science between two distant Ukrainian lands: Volyn and Southern Ukraine. Volyn and Southern Ukraine are connected by many historical threads, human destinies. Some of the manifestations of interest to the history of Volyn and collaboration with Volyn scientists were in the activities of scientific societies South of Ukraine: Odesa society of history and antiquities, Scientific archival Commission in Yekaterinoslav, Historicalphilological society at Novorossiysky University, the City Museum of antiquities of the province of Kherson in Kherson.

An article "Cossack graves in Berestechkoî by Dmytro Doroshenko was published on the pages of the 8th issue of the magazine Scientific archival Commission in Ekaterinoslav in "the Chronicleî. In the article the historian highlighted the history of the battle and described his impressions about the state of monuments. He visited the battlefield near Berestechko. Historians from Volyn and Southern Ukraine met at archaeological congresses. Volyn was mentioned on the pages of famous works of South Ukrainian historians D. I. Yavornytskyi, M. F. Komar and M.M. Arkas. F. I. Leontovich wrote a work on the history of the legal status of Jews and peasants in the Ukraine, comparing the Lithuanian statutes and the Pravda of Rus, which is largely based on the study of a Second Volyn Statute and Volyn acts. The work of V. Bidnov in 1908 on the position of the Orthodox Church in the Commonwealth was a master's thesis, a purely scientific work, although it had small features of the Orthodox worldview. The author evaluated the events from the point of view of the Orthodox, nobility, bourgeoisie and clergy of Volyn. V. Bidnov carefully collected information about the dissatisfaction of the Volyn people with the

${ }^{30}$ И. Стрельбицкий, Униатские цеекковные соборы с кониа XVI века до возсоединения униатов с православною цеековью: исторический очерк, Изд. 2-е., (Одесса, 1891), 164. 
ISSN 2078-6077. Наукові зошити історичного факультету Львівського університету. 2018-2019. Випуск 19-20. Proceedings of History Faculty of Lviv University. 2018-2019. Issue 19-20.

efforts of Catholics, which were aimed at correcting Volyn. M. P. Smirnov published an article under the title "The fate of the red or Galician Rusî in St. Petersburg in 1860, which he defended as a master's thesis. He traced the main stages of development of Galicia from Kiev times to 1387, before its accession to Poland. The master's thesis of the Privat-associate Professor of Novorossiysk University P.A. Ivanov "The historical fate of Volyn landî was devoted to the study of medieval history.

Thus, in the studies of southern Ukrainian historians Volyn appeared in historical and ethnographic essays of the tourist type, in the General context of studies of social and legal order of the Grand Duchy of Lithuania, in the works on the history of Volyn, which is reflected in their names. Despite the fact that only the works of the latter group can be considered a fundamental contribution to the historiography of the Volyn region, all of these groups, the works and the authors have performed an important mission: in a remote Volyn region in the South, they met with local readers and this unique Ukrainian land at first.

Keywords: Volyn, Southern Ukraine, historical science, historiography.

\section{REFERENCES}

Antonovych, Volodymyr. "Rec. na: Ivanov P. A. "Istoricheskie sud'by...," Kievskie universitetskie izvestija, (1896): 3-5. (in Russian)

Bednov, V. Pravoslavnaja Cerkov'v Pol'she i Litve (po Volumina Legum). Ekaterinoslav, 1908. (in Russian)

Hrushevs'kyj, Mykhaylo. "Rec. na: Ivanov P.A. "Istoricheskie sud'by...," Zapysky Naukovoho Tovarystva im. Shevchenka, t. 9 bibliografija, (1896): 4-9.

Lystuvannya tovarystva z zakladamy, Derzhavnij arhiv Odes'koï oblasti, F 93, Op 2, Spr 5, 105 ark (in Ukrainian)

Dovnar-Zapol's'kyi, Mytrofan. "Rec. na: Ivanov P.A. "Istoricheskie sud'by...," Zhurnal ministerstva narodnogo prosveshhenija, No. 4, (1896): 332-377 (in Russian)

Doroshenko, Dmytro. Po ridnomu kraju: (podorozh. vrazhennjaj zamitki). L'viv, 1930. (in Ukrainian)

Doroshenko, Dmytro. Kozackie mogily pod Berestechkom. Letopis' Ekaterinoslavskoj uchenoj arhivnoj komissii Ekaterinoslav, No. 8, 1912, 65-81. (in Russian)

Doroshenko, Dmytro. Moï spogadi pro nedavnye mynule. 1901-1914. Vinnipeg, 1949 (in Ukrainian)

Dubnov, Symon. 'Evrejskaja starina v g. Ostroge (1532-1792)î, Voshod, Oktjabr', 1894, 3-22. (in Russian)

Dubnov, Symon. Oblastnye kagal'nye sejmy v voevodstve Volynskom i v Belorussii (16661764). Voshod, Aprel', 1894, 25-45. (in Russian)

“Epistolyarna spadshhyna akademika D. I. Javornic'koho,o Vyp. 1: Listy vchenih do D.I. Javornic 'koho, ukladachi: S. Abrosimova ta in. Dnipropetrovs'k, 1997. (in Ukrainian)

Ivanov, Pavlo. Istoricheskie sud'by Volynskoi zemli. Odessa, 1895 (in Russian)

Ivanov, Pavlo. "Neskol'ko slov po povodu sochineniya A.V. Longinova “Knjaz' Fedor-Lyubart Ol'gerdovich,î Chtenija v istoricheskom obshhestve Nestora letopisca v Kieve, t. 8 (bibliografija), 1894, 23-35 (in Russian)

Ivanov. Kartka z istoriï Volini na pochatku XIV st., Zapiski naukovogo tovaristva imeni T. Shevchenka, t. II (1893), 119-146 (in Ukrainian)

Klepatskij, Pavel. Ocherki po istorii Kievskoj zemli. Odessa, 1912, t. I, Litovskij period. (in Russian)

Krip'yakevych, Ivan. Galic 'ko-Volins'ke knyazivstvo. L'viv, 1999. (in Ukrainian)

Kuchinko, Myhaylo. Volyns 'ka zemlja X-seredyny XIVst. Luc'k, 2002 (in Ukrainian) 
Linnichenko, Ivan. Otzyv ob uchenyh trudah P. Ivanova. Odessa, 1905(in Ukrainian)

Leontovich, Fedor. Istoricheskij obzor postanovlenij o evrejah v Rossii, Sion (1861): 10, 17, 24 nojabrja, 1, 8, 15, 22, 29 dekabrja; (1862): 13, 20, 27 aprelja (in Russian)

Leontovich, Fedor. Istoricheskoe issledovanie o pravah litovsko-russkih evreev, Kievskie universitetskie izvestija, (1864): 3-4. (in Russian)

Leontovich, Fedor. Krest'jane jugo-zapadnoj Rossii po litovskomu pravu XV-XVI st., Kievskie universitetskie izvestija, (1863): 10-11. (in Russian)

Leontovich, Fedor. Russkaja Pravda i Litovskij Statut, v vidah nastojatel'noj neobhodimosti vkljuchit' litovskoe zakonodatel'stvo v krug istorii russkogo prava, Kievskie universitetskie izvestija, (1865): 2-4. (in Russian)

Letopis’ Ekaterinoslavskoj uchenoj arhivnoj komissii. №. 6. 1910. (in Russian)

Letopis' Hersonskogo gorodskogo muzeja drevnostej Hersonskogo kraya za 1914 god. Herson, 1916. (in Russian)

Longinov, Arkadiy. O knjaze Ljubarte Ol'gerdoviche i ego potomkah, knjaz'jah Sangushkah. Trudy Vilenskogo otdelenija Moskovskogo predvaritel'nogo komiteta Syezda. Vil'no, 1893, 275-311 (in Russian)

Longinov, Arkadiy. O rodstvennyh svjazjah russkih knjazej s ugorskim korolevskim domom, Trudy Vilenskogo otdelenija Moskovskogo predvaritel'nogo komiteta Syezda. Vil'no, (1893), 313-328 (in Russian)

Siljuk, A. 130 rokiv vid dnja smerti M. D. Ivanisheva (1811-1874) - ukrayins'kogo istoryka, pravnyka, arheografa, doslidnyka Volyni, Kalendar znamennyh i pam'jatnyh dat Volyni na 2004 r. Upr. kul't. i turizmu Volin. obl. derzh. admin., Volyn. krayezn. muzej, Volyn. derzh. obl. univers. nauk. b-ka im. Oleny Pchilki. Luc'k, 2003, 97-99. (in Ukrainian)

Smirnov, Mihail. Spor mezhdu Litvoju i Pol sheju o pravah na Volyn'i Podoliju, Torzhestvennyj akt Rishel'evskogo liceja po sluchaju okonchanija 1862-1863. 5-71. (in Russian)

Smirnov, Mihail. Jagajlo-Jakov-Vladislav i pervoe soedinenie Litvy s Pol'shej, t. I. Odessa, 1868 (in Russian)

Smirnov, Mihail. Otchet o poezdke v gorod Vil'no. Prilozhenie $k$ statye 14 protokola zasedanija Uchenogo Soveta Novorossijskogo universiteta (1867) 75-77 (in Russian)

Strel'bickij, Ivan. Uniatskie cerkovnye sobory s konca XVI veka do vozsoedinenija uniatov s pravoslavnoju cerkov'ju: istoricheskij ocherk. Odessa, 1891. (in Russian)

Trudy odinnadcatogo arheologicheskogo syezda v Rossii v Kieve. 1899. t. II. Moskva,1902 (in Russian)

Jarmoshik, Ivan. Volin'v istoriko-kracznavchih doslidzhennjah XIX-XX stolit'. Zhytomyr, 2006 (in Ukrainian) 